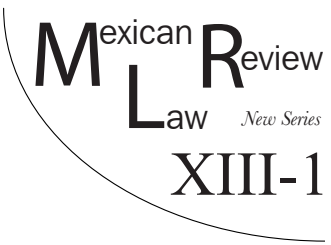

\title{
REVIEW OF THE INTERNATIONAL PATENT SYSTEM: FROM THE VENICE STATUTE TO FREE TRADE AGREEMENTS
}

\author{
Claudia Angélica Córdova GonzÁlez* \\ Mónica Guadalupe CHÁvez ElorzA**
}

\begin{abstract}
The current international patent system emerged within certain economic, political and social conditions in specific territories and periods. It has its historical roots in the Statute of Venice (1474), the Statute of Monopolies (1624), the United States Patent Law (1790), the French Patent Law (1791) and the Paris Convention (1883). Over time, these laws shaped a new model, which currently prevails. To strengthen the analysis of this article, the Agreement on Trade-Related Aspects of Intellectual Property Rights (1994), as well as free trade twentieth century agreements are integrated into the discussion. It is worth noting that each amendment stressed the economic relevance of the patent and its use to benefit certain economic elites through the creation of monopolies. Consequently, the debate on the purposes and nature of the international patent system has also been constant from its emergence to the present. This article provides basic elements for reflection about the origin, purposes and scope of national patent models implemented in Latin America within the global trend of scientific-technological innovation for development.
\end{abstract}

Keywords: Statute of Venice (1474), Statute of Monopolies (1624), United States Patent Law (1790), French Patent Law (1791), Paris Convention (1883).

RESUMEN: El sistema internacional de patentes vigente apareció a partir de ciertas condiciones económicas, políticas y sociales en territorios y periodos con-

* Candidate for a $\mathrm{PhD}$ in Development Studies from the Autonomous University of Zacatecas, and Master in Political Science from the same university.

** PhD in Public Policy from the School of Government and Public Policy from the Tecnológico de Monterrey, and Master in Applied Economics from the Colegio de la Frontera Norte.

This article is part of the research project A1-S-9013: "Evaluación de impacto de las politicas públicas en la productividad científica, tecnológica e innovadora en México", Convocatoria de Investigación Básica 2017-2018 SEP-CONACYT. 
Esta revista forma parte del acervo de la Biblioteca Jurídica Virtual del Instituto de Investigaciones Jurídicas de la UNAM

cretos. Se destacan dentro de sus antecedentes históricos el Estatuto de Venecia (1474), el Estatuto de Monopolios (1624), la Ley de Patentes de Estados Unidos (1790), la Ley de Patentes de Francia (1791) y el Convenio de París (1883). Con el paso del tiempo estos fueron configurando un nuevo modelo que es el que impera actualmente. Para fortalecer el análisis del presente artículo se integra a la discusión el Acuerdo sobre los Aspectos de los Derechos de Propiedad Intelectual relacionados con el Comercio (1994), así como tratados de libre comercio del siglo XX. Cabe resaltar que con cada enmienda fue dominando la importancia económica de la patente y el uso de esta para beneficiar a ciertas élites económicas por medio de la creación de monopolios. Como consecuencia de lo anterior, el debate sobre los propósitos y naturaleza del sistema internacional de patentes ha sido también una constante desde su aparición hasta la actualidad. Este artículo da elementos básicos para la reflexión sobre el origen, los fines y los alcances de los modelos nacionales de patentes instituidos en Latinoamérica en la tendencia global de la innovación científica-tecnológica para el desarrollo.

Palabras clave: Estatuto de Venecia (1474), Estatuto de Monopolios (1624), Ley de Patentes de Estados Unidos (1790), Ley de Patentes de Francia (1791), Convenio de París (1883).

\section{TABle of Contents}

I. INTRODUCTION.

II. Origins of the Patent System .................................................... 68

1. Statute of Venice..................................................................... 68

2. Statute of Monopolies ......................................................... 71

3. French Patent Law ................................................................ 74

4. United States Patent Law..................................................... 77

III. International Patent System. Contrasts Between Laws and First Elements Towards Homogenization ................................ 80

IV. International Patent System. A New Turn................................ 87

1. Establishment of the Paris Convention.................................... 87

2. Formation of the Patent Cooperation Treaty …........................ 90

V. Intellectual Property and International Trade ....................... 92

1. Agreement on Trade-Related Aspects of Intellectual Property Rights (TRIPS) .................................................. 94

2. Free Trade Agreement ..................................................... 96

3. Regional Economic Integration in South America.................... 97

VI. Goncludsion n.................................................................... 99 


\section{INTRODUCTION}

The current international patent system emerged without a predetermined legal structure based on the fundamental principles of law, that is, it arose from certain economic, political and social conditions in specific territories and periods. At the beginning of the fifteenth century, some Italian city-states based their economic growth mainly on trade. Inventions, developed through the importation of foreign knowledge, played a central role in the merchants' guild, which promoted technological competitiveness. ${ }^{1}$ They saw the letters patent as a possibility of acquiring a monopoly for a certain time and sought to establish a regulatory system of inventions, which had changed over time and which currently has adapted to meet new global trends.

In some national and international reforms, they set out to establish precise parameters for the patentability of an invention, also to give greater certainty to the moral and economic rights of the inventors and/or owners of the patent, to broaden the territorial extension of the right to property, possession and/or exploitation of a patent, as well as the establishment of rules and penalties for the resolution of disputes, some of them derived from ius prohibendi. ${ }^{2}$ It should also be noted that with each amendment, the economic relevance of the patent and the proclivity to favor certain economic elites through the creation of monopolies were highlighted. As a result, the debate on the purposes and nature of the international patent system has also been a constant from its emergence to the present.

This article deals with three relevant topics to deepen the patent analysis. In the first place, a study of the relevant ordinances and conventions in the matter has been made starting with the 1474 Statute of Venice up to the current dominant system, in particular the 1883 Paris Convention, the 1994 Agreement on the Aspects of the Rights of Trade-related Intellectual Property (TRIPS), and the 1978 Patent Cooperation Treaty (PCT). Likewise, the institution created to manage TRIPS will be discussed; this will identify the particularities and contexts under which those ordinances and conventions were established.

Secondly, an analysis of the Free Trade Agreements (FTA) and TRIPS, which emerged in the 1990s and which influenced the adjustment of the local legislation in the signatory countries in accordance with the International Patent System, will be carried out taking as examples the cases of the Mexican and the Andean Communities.

Finally, some conclusions are presented regarding the elements analyzed on the origin and purposes of the International Patent System. Therefore, we

1 G. Allen Nard et al., Constitutionalizing Patents: From Venice to Philadelphia, Review of Law \& Economics, Vol. 2, No. 2 (2006).

2 This means the power of the owner of an industrial property right to prevent its use by third parties. See http://dej.rae.es/lema/ius-prohibendi. 
expect to identify the possible future scenarios for the system and its effects at a global level and especially in Latin America.

\section{Origins of the Patent System}

The first antecedent of the International System of Representatives is the Statute of Venice that emerged in the fifteenth century, in the city of Venice, in the context of a commercial boom and high regional competitiveness that sought to boost innovation.

Subsequently, in 1623, the Statute of Monopolies was established in England. It derived from the disputes between the Crown and the Parliament to eliminate its discretion in granting monopolies to certain people who affected the population negatively by rising merchandise prices and, at the same time obstructed the progress of certain industries. The Statute of Monopolies together with the Navigation Laws and the establishment of the Bank of England became substantial preindustrial legal elements for the consolidation of the Industrial Revolution in England. ${ }^{3}$ Both the Statute of Monopolies and the Navigation Laws sought to protect and promote local industry and commerce against international competition. On the other hand, the Bank of England served as the main source of public financing for industry and commerce. Other nations viewed the English experience and adapted it to their regions. Years later, the law emerged in the United States in 1790, in France in 1791, and in Germany in 1877.

In 1873, the International Exhibition of Inventions in Vienna was marked by the absence of inventors from other countries. They feared that their inventions would be stolen and marketed in other places since there was no international law that guaranteed property and exploitation right. It should be stressed that in that period the patents were validated only within the country where they were assigned and there was no penalty for the use of third parties globally. This event was a precursor of the 1883 Paris Convention.

\section{Statute of Venice}

In 1421, during the Renaissance, the first letters patent or privilege was granted in the Republic of Florence to Brunelleschi for the design of a ship, ${ }^{4}$

3 Silvana A. Figueroa Delgado, El Estado y el trabajo científico en el proceso de DESARROLlo (Universidad Autónoma de Zacatecas 2015).

4 The privilege was expressed through a letters patent. This public document set forth the privileges granted, this being the reason why a patent is currently named "patent" to an exclusive right of an invention. Lucila Díaz Rönner et al., Propiedad Intelectual y nociones de vida: relaciones, condiciones de posibilidady desafios, 12(35) Revista Iberoamericana de Ciencia, Tecnología Y SOCIEDAD 14-15 (2017), http://wwrerevistacts.net/volumen-12-numero-35/328-articulos/785-propiedad-intelectual-y-nociones-de-vida-relaciones-condiciones-de-posibilidad-y-desafios. 
and the first Patent Statute was created to protect the guilds; that is, it gave them monopoly as a tool to hinder competition. ${ }^{5}$

However, the first antecedent of the International System of Representatives was the Statute of Venice in 1474, unlike the first, considered utility, novelty and non-obviousness within its patentability requirements; it should be practical, that is, used or operated within a certain time and it was considered quid pro quo of knowledge by monopoly. ${ }^{6}$ It is known that about one hundred privileges or letters patent were granted or requested for industrial inventions between 1475 and $1550 .{ }^{7}$ This Statute is considered by many authors as the first patent law. ${ }^{8}$

It is important to highlight the differences in the political, social, and economic context between the city of Venice and Florence that allowed the Statute to emerge in the first place and not in the second. According to Allen and Morris ${ }^{9}$, the fifteenth-century Venetian society was structured in groups, those who benefited from trade were the well-off classes with the patricians on top, an oligarchy that occupied the high command of the government and remained in their positions for a short time, and represented 2 percent of the population. In this pyramid, the cittadini originari, who held the bureaucratic positions, remained in their positions for many years and were responsible for verifying compliance with the application requirements and the granting of the letters patent. They represented 5 percent of the population. Finally, there was the popolo, which was integrated by the associations or neighborhood groups and by guilds or unions of the arts and crafts that indirectly influenced the decisions of the patricians. As the unions did not have great power to implement letters patent through their organizations, they required the State to intervene; in addition, thanks to the structuring of society and its functions, acts of corruption were limited in the process of assigning privileges, leaving income to the State.

5 G. Allen Nard et al., Constitutionalizing Patents: From Venice to Philadelphia, Review of Law \& Economics, vol. 2, No. 2, (2006).

6 Bruce Bugbee, Genesis of American Patent and Copyright (Washington, DC: Publics Affairs Press, 1964) (1967), and Giulio Mandich, Venetian Patents, 30 Journal of Patent Office SOCIETY 176 (1948).

7 Edith Penrose, La economía del sistema internacional de patentes 6 (Siglo Veintiuno, 1951) (1974).

8 Lucila Díaz Rönner et al., Propiedad Intelectual y nociones de vida: relaciones, condiciones de posibilidad y desafios, 12(35) Revista Iberoamericana de Giencia, Tecnología y Sociedad (2017), http://wrere.revistacts.net/volumen-12-numero-35/328-articulos/785-propiedad-intelectual-y-nociones-devida-relaciones-condiciones-de-posibilidad-y-desafios; Edith Penrose, La ECONOMía DEL SISTEMA INTERnACiOnal DE PATENTEs (Siglo Veintiuno, 1951) (1974); Mariano Zukerfeld, Las regulaciones del acceso a los conocimientos en el período preindustrial. Introducción a una sociología histórica de la propiedad intelectual, 17(32) REDEs, 17, 37 (2011), http://wwre.redalyc.org/pdf/907/90722371001.pdf.

9 Id. at 240-242. 
Venice became a pole of attraction for inventors, who arrived from all over the world seeking to benefit from the letters patent. This resulted in the consolidation of the Statute further in time. The unions made sure that the inventors spread their knowledge with a group of apprentices under their charge. Thus, it can be seen that the inventor had the individual right, but his exercise was of a group nature. The logic of the privilege can be understood as the monopoly years in exchange for the training period of at least two generations of apprentices, as a way of ensuring the transfer of knowledge of the immigrant teacher. ${ }^{10}$

In Florence, the unions were much stronger to offer lasting opportunities. They were governed by private norms and could grant privileges, so they did not need the intervention of the State. This way of allocation of letters patent was less expensive without state interference. Also, within the Florentine guilds, there were fewer internal interest groups that sought to oppose the innovation of each other in order to protect their inventors. ${ }^{11}$ Lastly, it should be emphasized that in Florence the guilds were the direct beneficiaries of trade, while in Venice they were all: patricians, cittadini, popolo and inventors.

It should be stressed that the patent letter was conferred for both inventions and for what is known today as copyright. There are three relevant aspects related to the Statute: first, the duration of the privilege for ten years in an invention of new arts and machines (new knowledge or imported). ${ }^{12}$ Second, requirements were established to grant the privilege; from that moment on an ordinance would replace the process that was previously a personal request; and third, the rules through a mandatory registration, which after the expiration of the patent letter would allow the transmission of knowledge to the public in favor of the economic development of the territory. ${ }^{13}$ Finally, once the right was granted, it had to be exploited, otherwise the privilege of the inventor would be revoked. ${ }^{14}$

Penrose considers that the Statute somehow helped to activate the inventive capacity "in the 15 th century the systematic use or monopoly privilege

10 Mariano Zukerfeld, Las regulaciones del acceso a los conocimientos en el período preindustrial. Introducción a una sociología histórica de la propiedad intelectual, 17(32) REDEs, 34 (2011), http://wrere.redalyc. org/pdf/907/90722371001.pdf.

11 Frank D. Prager, The Earthly Growth and Influence of Intellectual Property, 34 (2) JouRnAL of the Patent Office Society, 126-128 (1950), http://wrewe.compilerpress.ca/Library/Prager\%20 Early\%20Growth\%20E\%20Influence\%20o\%20IP\%207POS\%201950.htm.

12 Samuele Romanin, Storia Documentata Di Venezia, vol. 4, 485 (Giusto Fuga, ed., 1913).

13 Mariano Zukerfeld, Las regulaciones del acceso a los conocimientos en el período preindustrial. Introducción a una sociología histórica de la propiedad intelectual, 17(32) REDEs, 26-29 (2011), http://wrere. redalyc.org/pdf/907/90722371001.pdf.

14 Alejandro García Sandoval, Derecho de patentes sobre invenciones biotecnológiCAS 5 (Universidad de Cantabria 2018). 
granted to inventors emerged in Venice in order to stimulate the invention". ${ }^{15}$ However, for Zukerfeld this ordinance intended more to protect knowledge for economic benefit of Venice, than to stimulate innovation and novelty "it seems clear that it was not of interested to create new knowledge in the territory of arrival, as much as the exploitation and dissemination of that knowledge that had demonstrated its effectiveness in other times and spaces". ${ }^{16}$

We must not lose sight of the fact that one of the reasons for granting these privileges was to preserve endogenous knowledge and capture for themselves the knowledge coming from abroad to expand their capacities, a condition that would allow them to depend to a lesser extent on foreigners.

\section{Statute of Monopolies}

Fourteenth-century England was considered the starting point of capitalism in the world with the gradual implementation of monarchical measures aimed at strengthening and protecting the internal market. This resulted in the expansion of the productive structure, the increase in regional inventiveness and the final immigration of people from Germany, Belgium, France and Italy, who were experts in the development of goods, and whose knowledge and skills were used to train and employ residents in the manufacture of products that were previously imported. ${ }^{17}$

Lipson noted that in the mid-sixteenth century and up to the first half of the seventeenth century, a state tactic was to empower an individual or a group of individuals acting as a corporation. Queen Elizabeth I, in the hands of her advisors, structured the system to grant monopolies and concessions in a discretionary manner with the objective not only to make England economically independent but also to benefit certain groups such as the same crown. This procedure gave rise to the so-called monopoly patents. Initially, four types were identified, which were the antecedents to the Statute of Monopolies. ${ }^{18}$

The first category of patents is related to the ability to invent, the intelligence or the effort of an individual discovering something beneficial for his community, to which some technical process brought from abroad is added. The second category was configured as licenses that were executed by force

15 Edith Penrose, La economía del sistema internacional de patentes 6 (Siglo Veintiuno ed., 1951) (1974).

16 Mariano Zukerfeld, Las regulaciones del acceso a los conocimientos en el período preindustrial. Introducción a una sociología histórica de la propiedad intelectual, 17(32) REDES, 31 (2011), http://wrere.redalyc. org/pdf/907/90722371001.pdf.

17 Silvana A. Figueroa Delgado ET al., La ciencia y tegnología en el desarrollo: una VISIÓN DESDE América (Universidad Autónoma de Zacatecas 2009).

18 Ephraim Lipson, The Economic History Of England 352-361 (A. \& C. BLACK, LTD. 1943). 
of law and prevented the production of the merchandise by an unauthorized third party. The third category was granting an individual the power to supervise an industry or commerce; for example, the wine sales. Finally, the fourth category was the concession granted to one or more persons on an industry that was in operation. Sometimes a monopoly was given within the last category derived to the first, i.e. the monopoly invention and was extended to the manufacturing process.

The monopoly of an established industry (fourth category) generated a dispute between the Crown and Parliament, because it affected the interests of the society: the monopolists set the price, the volume and the manufacturer; mostly they produced basic consumer products, which generated discomfort in the population. The bad administration and the abuses in the granting of monopoly patents showed the scarce intentions to strengthen the industry, that is, the holders of the patents benefited economically and at the same time the established industries were dismantled.

It is worth underlining that both the Crown and the Parliament had the power to grant monopoly patents. The difference is that the Crown could do so in a discretionary manner, and Parliament had to rely on the protective legislation for unions and peoples, which derived from the common law. ${ }^{19}$ Therefore, the Crown could ignore the common law for the assignment of a monopoly patent, but upon the arrival of the Monopoly Statute, both the Crown and the Parliament had to abide by the rule.

As a result of the recurring disagreements, the general discontent with the monopoly system and the pronouncement of the House of Commons, Queen Elizabeth I decided not to contradict this collective feeling of nonconformity. It was taken as a preventive measure and, facing of the possibility of irreversible consequences to her reign, the Queen issued a proclamation in 1610 in which she argued the deception under which some monopoly patents were granted, considering intervention as necessary. ${ }^{20}$

As a result of this real notification, several monopoly patents were declared without effect because they were detrimental to the common welfare. In addition to this, the most significant was the right to go to court to demand compensation for the damage caused by the use of a monopoly. Years later, this proclamation received institutional strength in the Monopoly Statute of 1624 .

The Statute of Monopolies was aimed at motivating the creativity and talent of the kingdom because in the 16th century England was surpassed by other regions as to the development of knowledge of certain industries such as mining and the manufacture of glass, paper and clothing. Furthermore, its dependence on foreign countries entailed the exit in large quantities of

19 C. Allen Nard et al., Constitutionalizing Patents: From Venice to Philadelphia, Review of Law \& Economics, vol. 2, No. 2 (2006).

20 Ephraim Lipson, The Economic History Of England (A. \& C. BLACK, LTD. 1943). 
bullion for the payment of goods (cereals, oil, leather, gunpowder, among others) purchased abroad. In this way, the Statute was expected to reduce dependence with other regions.

As mentioned earlier, the Statute declared several monopolies illegal, mainly those related to the purchase, sale, manufacture, work or use of goods, leaving only the number one category of patents in effect, and making an exception to favor inventors.

That all monopolies and all commissions, subsidies and patent letters so far made or granted, or so far for doing or being granted to any person or persons, political or corporate bodies, of or for the sole purchase sale, manufacture, work, or the use of anything with this kingdom... are completely contrary to the laws of this kingdom, and in no way should they be used or executed. ${ }^{21}$

Also, this ordinance excluded corporate or political organizations or related to them in obtaining monopolies. "And also be promulgated by the aforementioned authority, any person and persons, political and corporate bodies, who are or are subsequently, will remain and will be prevented and unable to have, use, exercise or put into use any monopoly...". ${ }^{22}$

On the other hand, numeral VI of the Statute indicated the time lapse of 14 years or less for the validity of a monopoly or concession patent, a faculty that only the true and first inventor or inventors of acts that had never been performed locally would enjoy, or have brought new knowledge from abroad.

The Statute was the strategy to strengthen the kingdom of England by promoting the development and protection of the knowledge necessary to reduce its dependence on some imported products and accumulate wealth. Penrose would point it out this way: "It was only part of the Crown's conscious policy to foster industry at the national level, which in turn was part of the overall objective of unifying the nation under a central authority, of destroying local powers and of making the country economically independent". ${ }^{23}$

One of the local powers to which Penrose alludes is the unions, which caused the backlog of innovations since they regulated the trades and marked the terms to practice them. At the same time, this ordinance is known as the law that represents all rights of the inventor, through the powers established therein in favor of the inventor and his work; not because it initiated the protection of the inventor's patent, but because it was the first general law of a modern state that established the principle that only the "true and first" inventor of a new manufacturing should be granted a patent monopoly. ${ }^{24}$

21 William Hyde Price, The English Patents Of Monopoly 136 (Boston, New York, Houghton, Mifflin, and Company, vol. I, 1906).

22 Id.

23 Edith Penrose, La economía del sistema internacional de patentes 8 (Siglo Veintiuno, 1951) (1974).

24 Id. at 10. 
It is important to note that three events that established the basis for consolidating the industrial revolution in England emerged simultaneously: the first was the Statute of Monopoly that would be granted as long as it did not transgress the public good. The second, the 1651 Navigation Law, that prohibited the importation into England by sea of goods on non-English ships. And third, the Bank of England, which was established in 1694 as the one in charge of investing in commerce through public debt. ${ }^{25}$

Protecting, rewarding and limiting inventions by the State allowed to multiply inventions without violating the public good, taking care of the domestic market, limiting maritime imports and ensuring the consumption of national products made by locals. Finally, it is worth noting that the Statute of Monopolies is the origin of the British patent law and is the precedent of the United States patent law.

\section{French Patent Law}

It can be stated that, in the case of France, the same happened as in Venice and England before the corresponding statutes were implemented: bad handling was detected in the issuance of monopoly concessions granted by the arbitrary will of the king. This method persisted, despite the vicissitudes of origin until the French Revolution broke out in 1789.

Before, France was structured by political and economic groups subject to rules decreed by the monarchy. The same acts regulated the activities of the guilds of merchants and craftsmen called "communautés". These unions enjoyed privileges that increased their impact on local economic, industrial and commercial activity. Their rules established who could exercise a craft offering protection in the exercise of their industry. In the event that an individual was not a member of the communauté, he was relegated from the exploitation of the industrial branches, and in the event of non-compliance with any norm of the union, he was penalized with high fines, confiscation or destruction of merchandise, material, and tools used in illegal industrial activity. ${ }^{26}$

All of the above is confirmed in the preamble of the Turgot edict (February 1776), registered on March 12 of the same year in the Parliament, which refers to the actions of the communautés:

In almost every city in our kingdom, the exercise of arts and crafts is concentrated in the hands of a small number of master craftsmen, gathered in communities, who alone, with the exclusion of all other citizens, can make or sell objects individuals of commerce of which they have the exclusive privilege;

25 Silvana A. Figueroa Delgado, El Estado y el trabajo científico en el proceso de DESARROLLO 24-25 (Universidad Autónoma de Zacatecas 2015).

26 Augustin-Gharles Renouard, Traté Des Brevets D’Invention 42-56 (Chez Guillaumin, Libraire, 1844). 
for those of our subjects who, for pleasure or need, are destined to the exercise of the arts and crafts, they can achieve this by acquiring the domain, to which they are received only after such long tests... The simplest work often does not. It can be carried out without resorting to several workers from various communities, without eliminating the slowness, infidelities, abuses and demands or pretensions promoted by their different communities, and the vagaries of their regime, arbitrary and interested... Therefore, these establishments are, relative to the State, an invaluable decrease in trade and labor... loss of wages and livelihoods... ${ }^{27}$

It is clear that in the face of such corporate intervention, the environment did not result in a larger amount of inventions since each finding would breach any established norm or law. This is not to imply that there was no granting of privileges for the monopoly or patent letters. In fact, there were no fixed rules established on its concession, in terms of time, motive, terms, conditions, etc.; for example, the manufacture of glass, the use of a mill, the elaboration of glasses, mirrors, canons, etc. ${ }^{28}$ Sometimes because of the context, which was not very profitable and limiting for inventors, migration to other countries was an alternative to develop and generate profits from their creations. $^{29}$

By means of a declaration in December 1762, the King established for the first time norms in the matter of granting patents and inventors right. These norms, effective until 1791, were a consequence of the deficient process of granting patents, since the inventors were not rewarded and assigned, in some cases, to people who did not require them for an unlimited time for real favoritism. In addition, the lack of use of some granted privileges obstructed the freedom of others to make use of them and impeded the development of local industry.

Some contributions of the declaration were (Declaration on the Granting of Patents and Inventor Rights, Dec. 24th , 1762, art. 1-7): ${ }^{30}$

a) The privileges would be granted to private persons, in their own name or in their name and the company's, under a fixed payment and would be executed according to form and content.

27 Anne-Robert Jacques Turgot, The Turgot Collection Writings, Speeches, And LetTers 274 (David Gordon, ed., Ludwing von Mises Institute, 2011).

28 Augustin-Charles Renouard, Traté Des Brevets D’Invention 77-81 (Chez Guillaumin, Libraire, 1844).

29 This was the case of Nicholas Briot, with his pendulum machine to mark coins, who migrated to England and created there one of the most beautiful coins in the time in Europe, as well as the creator of the paper and cylinder factory who emigrated to Holland, or the inventor of the looms, who emigrated to England and obtained great remunerations, among other cases (Id. at 82-84).

30 Id. at 85-87. 
b) The enjoyment of a privilege would be for 15 years with exceptions for extension at the discretion of the Crown or Parliament according to their relevance in the respective industry.

c) In the event that a holder died in the privilege course, his beneficiaries could not inherit it until an express confirmation of the authorities (Crown and/or Parliament) was issued, as long as some requirements were met, such as their ability to carry it out, verify the clauses that integrate it in a manner and substance, etc.

d) In case of not making use of the patent or using it and not succeed within one year, it would be revoked. Only under reasons or impediments legitimately verified by the holder would this not apply.

e) The publication of the privilege for public knowledge from the granting of the privilege.

Later, the impact of this statement would be strengthened with the edict of Turgot (1776), which was intended to abolish the guilds and their excesses of authority.

The Revolution of 1789 brought changes in the organization (background and form), forming new laws and freeing the industry and trade. In 1791 there was another important modification on the law regarding useful discoveries and means of securing ownership to authors, which took as reference the Statute of Monopolies of England of 1623. The reason for these changes in the law was the need to encourage industry and stop the migration of French inventors to other nations.

In summary, the following reforms stood out (Law of Useful Discoveries and Means of Securing Ownership to Authors, Jan. 7, 1791): ${ }^{31}$

a) The invention or new discovery became a property of the author. ${ }^{32}$ This way the law guarantees full enjoyment for a certain time (Art.1).

b) The invention is considered any unknown form that is added to any genre of the industry, that is, a new degree of perfection (Art. 2).

c) He who brings a new knowledge from abroad will be considered as an inventor and will enjoy the same privileges granted by law (Art. 3).

d) Present the invention to the corresponding authority, provide the exact description, drawings, designs, etc., so that at the time of receiving the title the information may be public (Art. 4).

e) To guarantee ownership to the inventor and temporary enjoyment, a patent or title will be granted (Art. 7).

31 Id. at 111-116.

32 In the Bouliers report presenting to the Assembly a decree project dated December 30, 1790 , it was pointed out that "If there is real property for a man, it is his thought... it is personal, independent, prior to all transactions... The invention, which is the source of the arts, remains that of property: it is primitive property; all others are just conventions...". Id. at 106. 
f) The validity of a patent will last five, ten or fifteen years, this at the request of the inventor, but will not be extended unless authorized by the legislative branch. This will apply to national inventions and to inventors with inventions brought from abroad (arts. 8 and 9).

g) The inventor has the right to keep the information of his registered invention secret under justifiable reasons before the legislative branch (Art. 11).

h) The inventor has the right to license ${ }^{33}$ his invention, i.e. someone else may obtain a benefit of the invention with the authorization of the owner (Art. 14).

i) Upon expiration of the patent, the invention or discovery will enter the public domain (Art. 15).

j) The inventor will be sanctioned with the revocation of the patent, in the following cases: using secret means not detailed in the description of his patent; failing to implement the patent for a period of two years from the date of the grant, without justification; obtaining a patent in France and applying for another one with the same purpose in another country. Likewise, the licensee will be under the same obligations as the inventor (Art. 16).

In sum, the French ordinance of 1791 was based on the precepts of the Statute of Monopolies, which was the antecedent not only in France but throughout the European continent. ${ }^{34}$ The non-truth would lie in the title deed that acquires the patents, the validity, the description, the intervention of the national government for the concession and the public domain of the knowledge of the invention, since previously there was only talk of rights and privilegi or monopoly of any industrial branch that was not mentioned for the invention and it was granted to certain favorite people of the king with the support of the communautés, promoting adverse conditions for the industrial and commercial development of the country.

\section{United States Patent Law}

The signing of the 1783 Treaty of Versailles led to two events that allowed the United States to begin its process of independence. On the one hand, the indirect participation in the Napoleonic Wars as a means to supply raw materials and their dependence and connection with England, which caused economic damage, mainly due to the decrease in exports of these resources to both European countries. On the other hand, the uneven local economic evolution between the north and the south promoted by the State unleashed

33 The license was considered by law as a personal property.

34 Edith Penrose, La economía del sistema internacional de patentes 13 (Siglo Veintiuno, 1951) (1974). 
strong disputes that affected the economy. The real condition of the State at that time was critical, since it was heavily indebted. The State implemented tariff rates and established a list of duty-free products, which included primary products. ${ }^{35}$

As for patents, few were issued in the English colonies in America, because they had as a priority agricultural activity and to provide England with raw materials. They were mainly responsible for the manufacture of products marketed in other countries and in their colonies themselves, as noted by Peskin: "the lucrative manufacturing function was denied to the colonists; however, they prospered as merchants within the British Empire and gained a lot of economic influence as the most important consumers of English goods". ${ }^{36}$ Nevertheless, it was not until the Independence process that patents acquired greater importance as a source of local industrial strengthening: "it was not until the Revolution [Independence] ...that patents began to be issued in large numbers for «industrial» or inventive purposes". ${ }^{37}$

In the 1787 constitution, the United States supported the advancement of science by granting exclusive rights to authors and inventors over their discoveries "To promote the Progress of Science and useful Arts, by securing for limited Times to Authors and Inventors the exclusive Right to their Writings and Discoveries...". ${ }^{38}$ Before its independence, it was subject to the rules established in England, whose main antecedent is found in the Statute of Monopolies. Despite its separation, it did not rule out the idea of promoting the invention.

The first federal patent law derived from the Constitution was the Patent Act approved on April 10, 1790, a few years after the country's independence. This ordinance pointed out to whom, on what and for how long a patent would be granted:

TRUN And stating that he, she or they have invented or discovered some useful technique, manufacturing, engine, machine or device, or any improvement not previously known or used, and praying for a patent to be granted, therefore, will be and It may be legal for and by said Secretary of State, the Secretary of the War Department and the Attorney General, or either, if they consider the invention or discovery useful and important enough to cause

35 Silvana A. Figueroa Delgado, El Estado y el trabajo científico en el proceso de DESARROLLO 43-53 (Universidad Autónoma de Zacatecas 2015).

36 Lawrence A. Peskin, Manufacturing Revolution (Johns Hopkins University Press, 2003) cited in C. Allen Nard et al., Constitutionalizing Patents: From Venice to Philadelphia, Review of LaW \& Economics, vol. 2, No. 2, 293 (2006).

37 It is worth mentioning that after independence patents were granted by each state, that is, they did not have a national validity. This point generated a debate on validity, coverage, etc. (Allen and Morris, 2004, 297). Edgar Burke Inlow, The Patent Grant 43 (Johns Hopkins Press, 1950).

38 Constitution of the United States [Const.], Constitution Article I, section 8, numeral 8, as amended, National Archives Catalog, September 17th 1787 (U.S.). 
patent letters... enumerating the statements and suggestions of this request, and describing such invention or discovery so clear, true and complete and, therefore grant it immediately to said petitioner or petitioners, his or her, administrators or assignees for any term other than over fourteen years. ${ }^{39}$

The person responsible for executing the Law of 1790 was the Patent Board composed of the Attorney General and the Secretaries of State and War, who would be responsible for examining the patent applications and deciding to grant it based on its usefulness and importance. Three points generated debate around the Law of 1790: a) Including invention and import patents in the law. The central point was to reward the person who imported technology and knowledge to the United States, granting her recognition as the local, unique and authentic inventor; $b$ ) The conditions under which the knowledge integrated within the patent will be disclosed; c) The desirability of establishing a system to examine and register patents. ${ }^{40}$

The first point was resolved by accepting import patents, thus granting a patent on new knowledge within the territory of the United States, which could be of foreign origin. "Any person...first to import to the United States from any foreign country, any art, machine, engine, device or invention, or any improvement in this regard, not before use or known in those States, [...] will benefit fully from this act, as if it were the original inventor or improver of these States". ${ }^{41}$ In the second, it was agreed that the description would have to be specific and detailed, so that it could be distinguished from a previous one in case a new one was presented, in addition to teaching someone else the technique so that at the end of the term the public could have access to that knowledge. Finally, the implementation of a national system that would verify the usefulness and importance of granting a patent was accepted.

At the end of the 19th century, the State resumed the protective and leading role of the country's production and trade, strengthened agriculture by encouraging research and development in the sector, and granted subsidies that placed the nation in a prominent place worldwide. On the other hand, the oil industry, the automotive industry, the metallurgical industry, among others, also improved as a result of scientific and technological advances.

When the First World War broke out, the United States had an economic expansion and it became one of the main suppliers of military weapons. Then the Great Depression emerged unexpectedly. The unexpected event was taken to counteract its effects; the architect was Franklin Roosevelt who made clear the importance of the State in the leadership of a nation, Figueroa

39 Patent Act (1790), section I, April 10th , 1790, the First United States Patent Statute, First Congress. Act to promote the progress of useful Arts, $\S \mathrm{I}$.

40 C. Allen Nard et al., Constitutionalizing Patents: From Venice to Philadelphia, Review of Law \& Economics, vol. 2, No. 2, 305 (2006).

41 Linda Grand de Pauw, ed., Documentary History of the First Federal Congress of the United States of America: House Representatives Journal 570 (The Johns Hopkins University Press 1977). 
Delgado adds: "The economic and social viability of these actions were then confirmed: it activated both demand and production, and the State proved to be the only agent capable, within the capitalist system, of reorganizing income. The fiscal deficit came in exchange for well-being". ${ }^{42}$

Years later, World War II detonated; the United States became a supplier of warlike instruments as it happened in the first confrontation. Thus, research and development institutions for defense were created. Consequently, the state intervened establishing a link with the universities to develop new useful knowledge for the productive sector and thus maintain commercial advantages globally.

At the beginning of the 18th century, two of the most important countries in the world, the United States and France, had firmly established their patent systems; although the laws were very recent, the practices on which they were founded were ancient. The previous system of privileges had given way to another system based on statutory law. The other countries began to follow that example by establishing their national patent laws.

\section{International Patent System. Contrasts Between Laws and First Elements Towards Homogenization}

As described above, from the fifteenth century the first privileges were given through a letters patent to grant an exclusive right to exploit knowledge. From that moment to the present, the parts of the knowledge that would be eligible for patent were defined.

It should be remembered that in the Statute of Venice the privilege was granted to different types of knowledge not only to inventions, but to literary works. In addition, there were no controversies for making use of knowledge found in other nations. Each law contributed to the evolution of what is now known as patent laws (see table 3.1), the most prominent being:

a) The name patent arises from the Venice patents letter, which granted the privilege of taking advantage of knowledge for a limited time for the economy, the generation of jobs and the independence of the foreigner, also the penalty for the lack of use of the privilege given.

b) The limitation of the Statute of Monopolies in the granting of patents to the unique and authentic inventors of the invention of national origin or brought from abroad for a limited time of fourteen years, as well as other requirements to obtain the patent letter.

c) French legislation grants ownership of industrial discoveries.

42 Silvana A. Figueroa Delgado, El Estado y el trabajo científico en el proceso de DESARROLLO 63 (Universidad Autónoma de Zacatecas 2015). 
d) The territorial extension of the validity of the patent right and unfair competition are integrated as part of the Industrial Property rights in the Paris Convention.

On the other hand, the process for the registration of a patent at international level is expedited in the Patent Cooperation Treaty. Roffe mentions other changes in the evolution of patent law:

The evolution of the system teaches us that patents were initially intended to reward and motivate the individual inventor, in order to improve the competitiveness of the internal industry and the industrialization process. These were the foundations of the first patent laws, for example, in countries like the United States and France. From that original conception, there were important changes. Today the great technological advances are not necessarily the result of individual works. They are the result of experiences of work teams in companies or research institutes. ${ }^{43}$

It is important to study the history of the political, economic and social conditions for which it was necessary to establish ordinances to regulate inventive activity, since knowing them allows us to understand the evolution of the international patent system, and resort to past events to predict current conflicts in the matter; as Zukerfeld points out: "In the midst of the intense current debates about possible reforms to intellectual property systems, it is likely - although in no way certain - that some novelty comes, like so many other times, from scrutinizing in the dark corners of the past". ${ }^{4}$

By doing a brief historical review, the United States is in a similar condition to that found in Venice or England several centuries ago. It has a high percentage of patent applications, in its territory and outside it. Thus, just from 1980 to 2010, the United States went from 104329 to 490226 patent applications in the form of the Patent Cooperation Treaty (PCT) ${ }^{45}$. Likewise, during the period of 1996-2010, it registered 1237060 applications for PCT patents, representing 31 percent of applications made in member countries of the Organization for Economic Co-operation and Development $(\mathrm{OECD}) \cdot{ }^{46}$

43 Pedro Roffe, Evolución e importancia del sistema de la propiedad intelectual, 37(12) COMERCIO EXTERIOR, 1045 (1987), http://revistas.bancomext.gob.mx/rce/magazines/205/5/RCE5.pdf.

44 Mariano Zukerfeld, Las regulaciones del acceso a los conocimientos en el período preindustrial. Introducción a una sociología histórica de la propiedad intelectual, 17(32) REDES, 36 (2011), http://wrere.redalyc. org/pdf/907/90722371001.pdf.

45 Patent Cooperation Treaty [PCT], done at Washington, June 19th, 1970, amended on September 28, modified on February 3, 1984, and on October 3, 2001.

46 Raúl Delgado Wise et al., La innovación y la migración calificada en la encrucijada: reflexiones a partir de la experiencia mexicana, 47 Remhu-Revista InTERdisciplinar Da Mobilidade Humana (2016), http://wrwre.scielo.br/scielo.php?pid=S1980-85852016000200153Escript=sci_abstractËtlng=es. 
The United States has a well-articulated educational, productive and commercial system, so experts in a wide range of knowledge areas immigrate to exploit their knowledge. Many of them conduct research or have patented their inventions, because if they did so in their country of origin, they would not have the same benefit, a condition that is used by the United States to continue capturing markets. Between 2006 and 2010 there were 205,446 migrant inventors in the world; the United States captured 57.1 percent of these. Moreover, 117,244 inventors residing in the United States were born abroad. ${ }^{47}$

The differences and similarities between the main statutes and patent laws analyzed are presented in a comparative way (see table 3.1), to highlight the process of their evolution and the first document created in this regard in the Paris Convention.

\section{Table 1. Differences and Similarities Between the Main Statutes and Laws of National Patents}

\begin{tabular}{|c|c|c|c|c|}
\hline Descriptor & $\begin{array}{c}1474 \\
\text { Venice Statute }\end{array}$ & $\begin{array}{c}1623 \\
\text { England Monopoly } \\
\text { Statute }\end{array}$ & $\begin{array}{c}1790 \\
\text { United States } \\
\text { Patent Act }\end{array}$ & $\begin{array}{c}1791 \\
\text { French Patent Law }\end{array}$ \\
\hline $\begin{array}{l}\text { Subjects who } \\
\text { receive the } \\
\text { monopoly }\end{array}$ & $\begin{array}{l}\text { Pre-Statute: fa- } \\
\text { vorites of the king } \\
\text { and guilds } \\
\text { Post-Statute: in- } \\
\text { ventor and person } \\
\text { who imported } \\
\text { new knowledge, } \\
\text { technique, etc. }\end{array}$ & $\begin{array}{l}\text { Pre-Statute: fa- } \\
\text { vorites of the king } \\
\text { and guilds } \\
\text { Post-Statute: in- } \\
\text { ventor and person } \\
\text { who imported } \\
\text { new knowledge, } \\
\text { technique, etc. }\end{array}$ & $\begin{array}{l}\text { Pre-Law: favor- } \\
\text { ites of the king } \\
\text { and guilds } \\
\text { Post-Law: inven- } \\
\text { tor or inventors } \\
\text { and person or } \\
\text { persons who } \\
\text { imported new } \\
\text { knowledge, tech- } \\
\text { nique, etc. }\end{array}$ & $\begin{array}{l}\text { Pre-Law: favor- } \\
\text { ites of the king } \\
\text { and guilds } \\
\text { Post-Law: } \\
\text { inventor and } \\
\text { person who } \\
\text { imported new } \\
\text { knowledge, } \\
\text { technique, etc. } \\
\text { and licensee. }\end{array}$ \\
\hline $\begin{array}{l}\text { Regulation of } \\
\text { rights and/or } \\
\text { obligations }\end{array}$ & $\begin{array}{l}\text { Inventions and } \\
\text { copyrights. }\end{array}$ & $\begin{array}{l}\text { Invention or } \\
\text { processes and } \\
\text { products. }\end{array}$ & $\begin{array}{l}\text { Invention of } \\
\text { processes and } \\
\text { products. }\end{array}$ & Inventions. \\
\hline $\begin{array}{l}\text { The previous } \\
\text { monopoly } \\
\text { statute/law is } \\
\text { the result of } \\
\text { social conflicts }\end{array}$ & $\begin{array}{l}\text { Conflict of na- } \\
\text { tional and regional } \\
\text { classes (patricians, } \\
\text { cittadini, popolo, } \\
\text { guilds, and inven- } \\
\text { tors) }\end{array}$ & $\begin{array}{l}\text { Conflict of } \\
\text { national classes } \\
\text { (Crown, Parlia- } \\
\text { ment, society, } \\
\text { guilds, and inven- } \\
\text { tors) }\end{array}$ & $\begin{array}{l}\text { International } \\
\text { conflict (US } \\
\text { independence, } \\
\text { protection of the } \\
\text { national indus- } \\
\text { try, world }\end{array}$ & $\begin{array}{l}\text { National and } \\
\text { class conflicts } \\
\text { (Crown, guilds, } \\
\text { inventors and } \\
\text { society) focused } \\
\text { mainly on }\end{array}$ \\
\hline
\end{tabular}

47 Özgür Topkaya, Emigration of Innovative Workforce in the Light of Patent Data, 195 ProcediA Social And Behavioral Sciences, 46 (2015), https://wrwresciencedirect.com/science/article/pii/S1 877042815036496 . 


\begin{tabular}{|c|c|c|c|c|}
\hline & & & $\begin{array}{l}\text { positioning as a } \\
\text { war supplier in } \\
\text { World Wars I } \\
\text { and II) } \\
\text { regional social } \\
\text { conflicts (north- } \\
\text { south). }\end{array}$ & $\begin{array}{l}\text { reducing the } \\
\text { emigration of } \\
\text { inventors. }\end{array}$ \\
\hline $\begin{array}{l}\text { Does the post } \\
\text { Statute/Law } \\
\text { monopoly } \\
\text { generate new } \\
\text { conflicts? }\end{array}$ & $\begin{array}{l}\text { It privileges inven- } \\
\text { tors, guilds and } \\
\text { the State. }\end{array}$ & $\begin{array}{l}\text { It privileges inven- } \\
\text { tors and the State. }\end{array}$ & State privilege. & $\begin{array}{l}\text { Privilege to lo- } \\
\text { cal inventors. }\end{array}$ \\
\hline $\begin{array}{l}\text { Differences } \\
\text { in the dura- } \\
\text { tion of the } \\
\text { monopoly, } \\
\text { its hereditary } \\
\text { extension, } \\
\text { and denomi- } \\
\text { nation }\end{array}$ & $\begin{array}{l}10 \text { years from } \\
\text { the grant of the } \\
\text { patent } \\
\text { Name: patents } \\
\text { letter }\end{array}$ & $\begin{array}{l}15 \text { years from } \\
\text { the grant of } \\
\text { the patent. The } \\
\text { extension of the } \\
\text { patent period, the } \\
\text { transfer of rights } \\
\text { and the hereditary } \\
\text { extension prior } \\
\text { approval of the } \\
\text { authorities. } \\
\text { Denomination: } \\
\text { monopoly letter. }\end{array}$ & $\begin{array}{l}14 \text { years from } \\
\text { the grant of the } \\
\text { patent. } \\
\text { Name: patents } \\
\text { letter. }\end{array}$ & $\begin{array}{l}5,10 \text { and } 15 \\
\text { years from the } \\
\text { grant of the } \\
\text { patent. The } \\
\text { extension of the } \\
\text { patent period, } \\
\text { the transfer } \\
\text { of rights and } \\
\text { the hereditary } \\
\text { extension prior } \\
\text { approval of the } \\
\text { authorities. } \\
\text { Name: patent } \\
\text { title. }\end{array}$ \\
\hline $\begin{array}{l}\text { Justification } \\
\text { for granting } \\
\text { the monopoly } \\
\text { (natural rights } \\
\text { of the inven- } \\
\text { tor, economic } \\
\text { benefit for the } \\
\text { inventor, for } \\
\text { the country, } \\
\text { etc.) }\end{array}$ & $\begin{array}{l}\text { Natural rights of } \\
\text { the inventor: com- } \\
\text { pensation for the } \\
\text { invested work } \\
\text { Incentive for } \\
\text { national industry } \\
\text { and economic } \\
\text { growth by promot- } \\
\text { ing the immigra- } \\
\text { tion of inventors. }\end{array}$ & $\begin{array}{l}\text { Natural rights of } \\
\text { the inventor: com- } \\
\text { pensation for the } \\
\text { work invested. } \\
\text { Incentive for } \\
\text { national industry } \\
\text { through inven- } \\
\text { tions. }\end{array}$ & $\begin{array}{l}\text { Natural rights } \\
\text { of the inventor: } \\
\text { compensation } \\
\text { for the invested } \\
\text { work. } \\
\text { Incentive for } \\
\text { national industry } \\
\text { and economic } \\
\text { growth. }\end{array}$ & $\begin{array}{l}\text { Natural rights } \\
\text { of the inventor: } \\
\text { compensation } \\
\text { for the invested } \\
\text { work. } \\
\text { Incentive for } \\
\text { national indus- } \\
\text { try and eco- } \\
\text { nomic growth, } \\
\text { avoiding the } \\
\text { emigration of } \\
\text { inventors. }\end{array}$ \\
\hline $\begin{array}{l}\text { De facto } \\
\text { or de jure } \\
\text { legislation }\end{array}$ & De facto. & De facto. & De jure. & De facto. \\
\hline
\end{tabular}

Source: Elaboration by author based on Penrose, 1974; Lipson, 1943; Renouard, 1840; Zukerfeld, 2011.

It is important to explain some points that are indicated in Table 3.1. The first point has to do with the arbitrariness or discretion of the competent authorities in granting the rights of privilege, letters patent or monopoly, which resulted in conflicts between different groups, mainly among those who were 
favored such as consumers and the competitors who sought to produce, use or sell the good in question.

As a second element, it is relevant to note that the duration of the monopoly varied depending on the statute/law, i.e. there were different benefits for the inventors. And also, their migration to the territories that offered them better was promoted.

Related to the duration of the monopoly, it is worth emphasizing none of the laws/statutes included clauses aimed at controlling abuses from the created monopoly. That is, the monopoly was established under the belief that it would be beneficial to boost the national industry and to protect the local market.

From the previous brief description, it is emphasized that the current patent system began by granting the first inventor the exclusivity to benefit from its creation for a certain time. As Pérez points out: "It is important to consider that a monopoly privilege was chosen at a historical moment in which a large part of the incipient manufacturing production was carried out under the monopolistic supply system for the so-called guilds". ${ }^{48}$ That is, the patent was used to strengthen and economically promote a region, as well as recover the investment made by the creator in the development of the invention. Furthermore, the inventor was informed that in case he failed to exploit the exclusivity, this would be lost.

In England, the Statute of Monopolies was established to stop the abuse of the Crown in the granting of monopoly letters to its favorites, because the growth, development and general welfare of the population was limited. The public interest won against the Crown and private interests. To date, within the industrial property rules of that country, there are still traces of the Statute of Monopolies that follow the same line as the Statute of Venice, stimulating the industry through legal mechanisms to grow inside and compete in the foreign market.

From the 18th century Patent Law of France the character of property acquired by intangible assets such as copyright and patents stands out, as they were a movable or immovable property. This item, "industrial property", as well as the monopoly of patents, has been and continues to be a point of debate due to its legal and economic nature, as well as its benefits and consequences in national, regional and international market-trade development.

The current legal figure of the patent remains within the industrial property right, that is, it is still considered a property of an intangible asset. Unlike the granting by the State or the Crown, a patent is currently granted to that or those (speaking of a legal entity) that meet the requirements requested by the institutions, regardless of whether or not they are the single authentic

48 Rafael Pérez Miranda, Patentes, monopolio y competencias. El Caso de los proDUCTOS Farmacéuticos, PPROPIEdAd INTElectual y farmacéuticos; Hacia una POlítica de Estado, Patentes, 180 (Instituto de Investigaciones Jurídicas, 2013). 
inventor. Likewise, it has an exclusive monopoly over a product or process for a certain time. And it is a case of monopoly because it limits exactly a third party to make use of the knowledge concentrated on a patent under the authorization and protection of the state.

Pérez Miranda ${ }^{49}$ mentions that precisely the monopoly represents one of the greatest problems of patents in our days due to the abuse it has generated. Consequently, agreements such as TRIPS, which are a reference for national laws on intellectual property for its signatories, establish the option of Compulsory License to curb exploitation excesses. However, the main industrialized countries, members of the World Trade Organization and also signatories of the TRIPS have not been flexible enough to the compulsory licensing system and have opted for internal antitrust laws, as is the case in the United States.

On the other hand, Pérez Miranda ${ }^{50}$ points out that we must be cautious with the interpretation of the term "abuse" as from a subjective perspective having a price of a patent drug higher than its average would be considered abuse even though the strictly legal vision would be to make valid a right of exploitation granted by the State.

Esplugas $^{51}$ makes a critique of intellectual property in its ethical-philosophical foundations and the utilitarian argument in its economic nature. Similarly, he points out that in the case of the patent and the copyright, they start from what in economics would be deemed very scarce, which limits or excludes the use by another subject or for another purpose. Both legal figures create an artificial shortage backed by the state through laws. Cole ${ }^{52}$ notes that the purpose of intellectual property is to generate scarcity through a legal monopoly. In the case of the patent, the law guarantees its holder a monopoly to obtain a profit.

The foregoing is contrary to the discourses that promote the creation of intellectual and industrial property laws that deal with guaranteeing the exclusivity of exploitation to inventors as compensation for effort, time, dedication, resources, among others. Likewise, some States, institutions, and international organizations argue that these legal tools encourage innovation, industrial strengthening, economic growth and the ability to compete in the global market.

49 Rafael Pérez Miranda, Tratado de derecho de la Propiedad industrial, 108 (Porrúa ed., 2011).

50 Rafael Perez Miranda, Patentes, monopolio y competencias. El Caso de los pro-

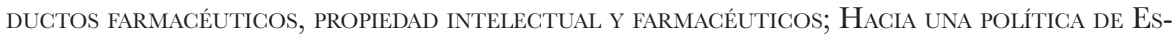
TADO, PATENTES, 186 (Instituto de Investigaciones Jurídicas, 2013).

51 Albert Esplugas, El monopolio de las ideas. Procesos de Mercado, Revista Europea de Economía Política, volumen III, Número 1, primavera 60 (2006).

52 Julio H. Cole, Patents and Copyrights: Do the Benefits Exceed the Costs? Journal of Libertarian Studies, 15 (4), 79-105 (2001) cited in Albert Esplugas, El monopolio de las ideas. Procesos de Mercado, Revista Europea de Economía Política, volumen III, Número 1, primavera 60 (2006). 
It should be noted that discussions about the ownership of intangible assets and the monopoly of patents have been a constant fact. This document only mentions some ideas or currents that address several elements that circulate around the international patent system, such as monopoly, property, quality, and nature.

Since national laws stipulated various guidelines, the Paris Convention sought to articulate general and common criteria. According to Perez Miranda ${ }^{53}$ and Penrose, ${ }^{54}$ these were the following:

a) The separation of the moral and economic law: moral law or public recognition as the inventor and economic or patent title.

b) Despite industrial and commercial differences, all countries will have equal treatment: "national treatment".

c) Duration of 20 years from the first patent application: right of priority.

d) The territorial validity of the patent is guaranteed in the member countries of the Union and in which it has been requested.

e) It covers patents, trademarks, industrial designs, industrial secrets, geographical indications and unfair competition.

f) The patent cannot be extended beyond the 20 years indicated.

g) Patents applicants can be both individuals and corporations.

h) The revocation of a patent will depend on each national law where the registration takes place.

i) International litigation is admitted for unfair competition; they can be carried out in a multilateral manner and the Union acts as an arbitrator.

j) It opens the possibility of migrating knowledge (as someone's property) and not a person; that is the importation of the owner or objects manufactured to other countries of the Union does not merit patent revocation.

$\mathrm{k}$ ) The principle of independence is established, that is the concession in one country does not require another to grant it. In addition, the denial of a patent in one country does not imply denying it in another.

l) The conditions of "abuse of the exercise of a patent" are established. Non-exploitation can only be sanctioned with compulsory non-exclusive license, it is requested after four years of the deposit of the application or three years after the granting of the right, whichever expires later, and only if the holder had not begun the exploitation two years after the first compulsory license was granted, can the expiration be decreed.

53 Rafael Pérez Miranda, Tratado de derecho de la Propiedad industrial (Porrúa ed., 2011).

54 Edith Penrose, La economía del sistema internacional de Patentes (Siglo Veintiuno, 1951) (1974). 
In the following section, the context in which the Paris Convention is established will be developed in greater depth and the most important changes will be explained in greater detail.

\section{International Patent System. A New Turn}

In the nineteenth century, the trend of the laws on industrial property legislation had spread. However, certain interest groups, traders, industrialists focused on exports, lawyers, etc., hoped to achieve territorial extension of rights exclusive of patents outside their borders, as well as the establishment of penalties for unfair competition, since it was thought that if they did not do so, they would be in a state of commercial disadvantage and the development of inventive ability would be hindered.

In 1884 the Convention of the Paris Union emerged for the protection of Industrial Property. It was formed by 79 countries and was known as the World Intellectual Property Organization (WIPO). ${ }^{55}$

\section{Establishment of the Paris Convention}

After 1815, the commercial and economic activity of the West increased exponentially. There were also advances in the arts and crafts; in industrial activity, trade ties between countries were similarly strengthened. Consequently, cooperation between nations regarding finance and the patent system was imperative. Nevertheless, two ways of thinking about these issues emerged. On the one hand, the highly active industry meant that creators demanded greater protection for their inventions. On the other hand, the consequences of adopting a repressive and monopolistic patent system for some less-developed nations, for example Latin American ones were argued by Penrose. ${ }^{56}$ Indeed, the discussion continued for a longer time, but in the end, the idea of implementing national and international patent laws prevailed.

In relation to national patent systems, by the nineteenth century several European countries, namely Russia, Prussia, Belgium, Holland, Spain, France, England, Germany, among others, had their own patent law. However, in 1873 the importance of the territorial scope of patents became evident, as a result of the Vienna Universal Exhibition. The United States was the first nation to express its opinion on the adverse effects that it would cause to appear in an international exhibition without protection of its inventions or products. Within the own nation, these were under its care, but outside, they were threatened by imitation and a probable commercial disadvantage. In

\footnotetext{
55 Id. at 54-57.

56 Id. at 16.
} 
addition, the country stressed that both national and international laws were necessary. As a result, subsequent meetings were held that culminated in an agreement in Paris in 1883 initially signed by thirteen nations, including four Latin American countries, of which only Brazil has remained constant from the beginning. ${ }^{57}$ The validity and stability of the Convention have allowed it to be the benchmark for the development of national patent laws, but all member nations have the freedom to articulate their laws under their own interests based on common principles.

The Paris Convention integrates several types of industrial property, as it refers to patents, trademarks, industrial designs, utility models, trade names, geographical indications and unfair competition. Furthermore, in general, the provisions contained herein are divided into four important areas: national treatment, right of priority, common rules and abuses in the exercise of the patent right.

National treatment refers to the equal rights and obligations that a foreign patent will obtain, such as a national patent, that is to say, a signatory country may register a patent in another nation and will receive the same treatment as its nationals. ${ }^{58}$ And in relation to countries not integrated into the Agreement, provided they have an industrial and commercial domicile in a member country the applicant must consider the requirements demanded by each national or regional office, in order to carry out its procedure, as are the cases of the United States Patent and Trademark Office (USPTO) and the Patent Office of Japan (JPO), those with differences in their processes, times and requirements.

Regarding the right of priority, any industrial property application submitted by a signatory country in the national institution may extend the request to other member countries according to their interests, taking as the date of application the first date of submission of this. This means that a Subsequent request will be a priority over other requests submitted by others interested likewise ${ }^{59}$ However, despite having the right of priority, it is of utmost importance to have extensive knowledge about the compliance of deadlines when to make it valid.

Finally, from the 1883 Paris Convention, some common rules are established which all the contracting states are obliged to respect and enforce. Some examples are: a) The granting, denial, cancellation, among others, of a patent will depend on each contracting country, which means that member nations are not obliged to submit to the decisions of another country; $b$ ) it is the right of the inventor to be named as such in the patent. In comparison with the Statute of Monopolies, it is not specified here that the patent will be

57 Pedro Roffe, Evolución e importancia del sistema de la propiedad intelectual, 37(12) COMERCIO EXTERIOR, 1041 (1987), http://revistas.bancomext.gob.mx/rce/magazines/205/5/RCE5.pdf.

58 Paris Convention for the Protection of Industrial Property, March 20, 1883.

59 Id. 
granted to the sole and authentic inventor, the granting of a patent as its legitimate right, since only the moral right but not the economic right over the patent is highlighted; c) if the sale of the product of a patent is limited by national legislation, this will not be grounds for responding negatively to a patent application or invalidating an existing one; and $d$ ) member countries have the right to establish in their legislation the granting of compulsory licenses. ${ }^{60}$ However, they will do so considering certain circumstances, for example:

The lack of industrial exploitation or insufficient exploitation of the patented invention, when the application has been submitted after three years from the grant of the patent or after four years from the date of filing of the patent application. In addition, the application must be rejected if the patent holder justifies its inaction on legitimate grounds. Moreover, the expiration of the patent cannot be foreseen except for the case in which the granting of a compulsory license would not have been enough to prevent abuse. ${ }^{61}$

This Convention adopted in 1883 had six subsequent revisions and suffered some final changes in the year 1979; the above allowed the territorial expansion of the exclusive right to an invention or other branches of industrial property, as well as the specifications on unfair competition. Currently, there are over one hundred member countries. The international body created to administer the Agreement among other Treaties is the World Intellectual Property Organization (WIPO).

The discussions that took place in the subsequent Conventions were related to I) the right of priority that implies that the inventor can register the patent in any member country of the Union as the sole inventor; II) the abuse of monopoly, specifically in relation to obligatory work and compulsory license; III) national treatment for foreign and national patents and IV) the independence of patents. ${ }^{62}$ It is necessary to clarify that the countries that signed the Convention may or may not at that time have national patent laws that would indicate such clauses; the United States had the most favorable national legislation for inventors, nationals or foreigners.

The obligatory work and compulsory license clauses generated major controversies. On the one hand, some people defended the protection and impulse to their national industries, while others proposed that the elimination of obligatory work would benefit even more the nascent industries.

...The work requirement may be indispensable for one nation, but unnecessary for another, and it is for this reason that there are so many differences of opin-

60 Compulsory licenses are those granted by a national institution, without considering the opinion of the patent owner. Somehow, it is expected to prevent the abuse of exclusive rights.

61 Paris Convention for the Protection of Industrial Property, March 20, 1883.

62 Edith Penrose, La economía del sistema internacional de patentes 85-86 (Siglo Veintiuno, 1951) (1974). 
ion regarding the usefulness of this type of patent system...in countries where the industrial activity is still in childhood, the requirement of compulsory labor is indispensable for the development of the national political economy and for the training of a professionally qualified workforce. ${ }^{63}$

In general, mandatory clauses have proven that they are inadequate to carry out the intention of legislators to promote national industrial activity. The long-standing experience of foreign countries indicates an extremely rickety use of compulsory exploitation... ${ }^{64}$

The tendency was in favor of eliminating obligatory work and for the benefit of the establishment of compulsory license. In addition, each nation established in its national laws whether or not the clauses that counter-monopoly abuses were approved. ${ }^{65}$

Finally, it is worth noting that this Agreement had several indications, which were established under a false principle of reciprocity since it operates on the equality of the parties. However, there are differences in economic capacity and technological development between the signatory countries and the possible applicants, implying that there is an immense application for patents from developed countries in underdeveloped countries, and in comparison to nationals. The exclusivity of excessively long exploitation discourages other researchers from searching on their own means the technology carried out by another researcher, since this effort is of no use. This also applies to fewer industrialized countries, which will stop conducting research in areas where more developed countries carry out research and development, given that their capabilities and level of development will allow them to obtain late successes. ${ }^{66}$

\section{Formation of the Patent Cooperation Treaty}

There is another important agreement in the International Patent System, the Patent Cooperation Treaty (PCT), signed by eighteen countries in June 1970 in Washington, D.C., and it entered into force eight years later. To date, there are 152 contracting countries. This treaty determines a system to

63 A. J. Michel, Introduction to the Principal Patent System of the World 10 (New York, 1936), mentioned in Edith Penrose, La economía del sistema internacional de PatENTES 142 (Siglo Veintiuno, 1951) (1974).

64 Richard Reik, Compulsory licensing of patents, 36 (5) The American Economic Review, 815 (1946), mentioned in Edith Penrose, La economía del sistema internacional de patentes 149 (Siglo Veintiuno, 1951) (1974).

65 Edith Penrose, La economía del sistema internacional de patentes (Siglo Veintiuno, 1951) (1974).

66 Rafael Pérez Miranda, Tratado de derecho de la Propiedad industrial, 45-46 (Porrúa ed., 2011). 
submit applications in different PGT signatory nations, through a single application. ${ }^{67}$ As mentioned, at the end of the PCT process each country will determine whether the application and/or grant of the patent are appropriate, through its patent offices.

The International Office in charge of WIPO coordinates and administers the PCT system, and also feeds on user experiences to improve its performance.

The phases of the PCT procedure are as follows: ${ }^{68}$

\section{International phase}

1) Submission of the PCT application.

2) International search report and written opinion.

3) International publication.

4) Supplementary international search (optional).

5) International preliminary exam (optional).

\section{National phase}

The processing of PCT application before the national or regional patent offices.

The first stage of the international phase begins with the filing of a local application at a national or regional patent office, and then the PCT application is made. There is a limited time of 12 months to submit it, from the local application, at the same national or regional office or if it is preferred, the presentation can be made directly at the WIPO Office.

Sixteen months after submitting the local application, the applicant receives an international search report and a written opinion from the Administration to whom the task is entrusted. The report contains quotations of patent documents among other relevant information related to probable patentability; this is accompanied by a written opinion that is a preliminary evaluation of the invention.

The third stage consists of the publication of the PCT application after eighteen months from the priority date in the PATENTSCOPE database

67 Occasionally it is confused that this Agreement collaborates with the filing of an application in different signatory countries with the granting of an international patent. WIPO only collaborates in the application process, but does not grant a patent with global validity. The single PCT application reduces time, money and effort of applicants, inventors or national offices in the application of a patent in each of the countries in which there is an interest in patenting. It is an international simplified presentation.

Organización Mundial de la Propiedad Intelectual, Introducción al Tratado de Cooperación en Materia de Patentes (2018).

68 Patent Cooperation Treaty [PCT], done at Washington, June 19, 1970, amended on September 28, modified on February 3, 1984, and on October 3, 2001. 
managed by the International Bureau. ${ }^{69}$ The technical part of the invention is revealed and, as of this moment, the applicant usually begins negotiations for industrial production, marketing, etc.

The applicant has the power to request at any time, before twenty-two months from the priority date, an additional report by another Search Administration. If your right is valid, there must be a supplementary international search report, and the applicant has the power to request an additional report from another Administration. The report will be ready within a period not exceeding twenty-eight months from the priority date. Also, a preliminary examination can be managed under the same terms and conditions as the report. This will allow the applicant to be more certain of the patentability of the invention and may make modifications to the PCT application with information from the report and/or preliminary examination.

The Administration responsible for the international preliminary examination shall forward the report to the national or regional Patent Offices for them to conduct patentability evaluations of the invention. With this stage, the international phase of the PCT application procedure is terminated.

On the other hand, the applicants at the end of the international process will make an indication of the countries in which they intend to register a patent, thus initiating the national phase. With the report made by the responsible Administration, each national or regional Office will assess, based on its laws, regulations and practices, the granting of the patent.

Once the national patent has been granted, any interested party has the right to object, appeal or request the revocation of the patent. Or in the case of the patent holder, it can promote infractions to users for the improper use of a patented invention or it can grant licenses from its patent.

\section{Intellectual Property and International Trade}

The establishment of the international patent system was largely driven to protect and promote international trade in the first half of the twentieth century. A group of countries agreed that it was necessary to reduce tariffs and trade barriers, since it was intended to open the range of business opportunities for stakeholders. In 1941, the first test was carried out with the endorsement of the Atlantic Charter in which the free exchange of goods and equal treatment for the signatory members was agreed. Another effort was the Havana Charter created to restore the economy and commerce of countries affected by military conflicts, as well as the formation of an International Trade

69 Regarding dates, there are several examples, such as the priority date, which is the date taken from the request made at the national or regional office, the local request. In addition, the date of submission of PCT application for the process and its stages will always be considered the priority date, the date of the local application. Likewise, there is the date of denial or withdrawal and an expiration date. 
Organization. This was done within the framework of the World Conference on Trade and Employment, but the work was in vain since they did not reach concrete agreements. However, in 1947 the idea was resumed in Geneva, and this time the negotiations concluded with the signing by 23 nations of the General Agreement on Tariffs and Trade (GATT) ${ }^{70}$ which entered into force in January 1948 through a Provisional Application Protocol..$^{71}$

The GATT at that time lacked full action, as well as legal personality at an international level since it required an organizational structure. Over time and with periodic work meetings, ${ }^{72}$ results were achieved on the issue of tariffs. In the last round of Uruguay, 1986-1994, tariff issues, subsidies, anti-dumping codes were addressed, referring not only to products but also to services and the resolution of disputes between countries. It should be stressed that in this meeting the topic of intellectual property was approached for the first time from a commercial perspective. On the other hand, the World Trade Organization (WTO) was created within the resolutions of that meeting ${ }^{73}$ through the Marrakech Agreement of 1994.

Most of the Agreements administered by the WTO are based on basic principles: most favored nation (MFN), equal treatment for all members and national treatment, equal treatment for nations and foreigners. ${ }^{74}$

The relationship between WTO and WIPO is agreed in the Cooperation Agreement between WIPO and WTO in 1995. This agreement aims to enforce Conventions that validate Intellectual Property Rights; as well as intellectual property rights with commerce, for example, the TRIPS, ${ }^{75}$ Paris Convention, Berne Convention, Rome Convention and Intellectual Property Treaty regarding Integrated Circuits, among others.

On the other hand, the cooperation between WIPO and WTO includes notices of national laws, the application of international TRIPS precepts based on the sixth article of the Paris Convention.

70 The General Agreement that date contained 35 articles relating to tariff concessions.

71 Organización Mundial del Comercio, Los años del GATT: de la Habana a Marrakech, OMC (2019), https://wrww.wto.org/spanish/thewto_s/whatis_s/tif_s/fact4_s.htm.

72 Work meetings were called rounds. In total, eight rounds were held: Geneva in 1947, Annecy in 1949, Torquay in 1951, Geneva in 1956, Dillon in 1960-61, Tokyo in 1973-1979, Uruguay in 1986-1994, see https://wwwewto.org/spanish/thewto_s/whatis_s/tif_s/fact4_s.htm\#rounds.

73 The Organization entered into force in January 1995. It is responsible for regulating commercial activity between countries and managing the diversity of trade agreements signed between nations, for example the General Agreement on Tariffs and Trade (GATT), the General Agreement on Trade in Services (GATS), the Agreement on Trade-Related Aspects of Intellectual Property Rights (TRIPS). Additionally, within the multiple tasks of the WTO is the trade policy review, consisting of, as the name implies, a study of the members' trade policies, for they must be promoted within the framework of transparency. This study estimates the importance of its application. It is the obligation of the members to undergo constant evaluation.

74 See https://wrww.wto.org/spanish/thewto_s/whatis_s/tif_s/fact2_s.htm.

75 Some of the treaties not covered by TRIPS are the WIPO Copyright Treaty, WIPO Treaty on the Interpretation and Execution of Phonograms, Brussels Convention. 


\section{Agreement on Trade-Related Aspects of Intellectual Property Rights (TRIPS)}

The Agreement is administered by the WTO, and it contains elementary rules that must be followed. It includes national laws on intellectual property of the member countries of the WTO-both copyrights contemplated in the Berne Convention ${ }^{76}$ and industrial property considered in the Paris Convention. The agreement increases the validity term for patents, expands their scopes of action and indicates the time of publication of inventions that required patent registration. Some of the main changes introduced by the TRIPS agreement are: the legal duration of patents should not be less than 20 years from the application; patents must cover all fields of technology (including drugs that were previously excluded in a series of countries). Patents must be published 18 months after the priority date. ${ }^{77}$ Finally, for the resolution of disputes, the signatory countries may resort to the WTO dispute settlement. ${ }^{78}$

Jorge separates in two groups the precepts contained in the TRIPS to carry out his study, specifically, in the matter of patents: a) the first group integrated the dispositions that have the determination to reinforce the right of the patent holder, and b) the second consisted of those that protect the consumer, in addition to promoting technology transfer. ${ }^{79}$

The first group refers to the duration of a patent (article 33), the susceptibility of an invention to patent (article 27), the rights granted (article 28) and national treatment (article 3). The second cites the mandatory conditions for patent applicants, exceptions to the rights granted, compulsory licensing modalities, as well as the transition periods, that is the time that countries have to incorporate these agreements into their national laws.

The exceptions to the patentability criteria of TRIPS ${ }^{80}$ are found in articles 27, paragraph 2, subsection a and b, and article 30, which indicates the Bolar exception, ${ }^{81}$ allows researchers to use a patented invention in their

76 The Berne Convention was signed on September 9, 1886. It is administered by WIPO and by the members of TRIPS.

77 Organización para la Cooperación y el Desarrollo Económicos, Manual de Estadísticas de Patentes de la OCDE 53 (OCDE-Ministerio de Industria, Turismo y Comercio-Oficina Española de Patentes y Marcas 2009).

78 Rafael Pérez Miranda, Tratado de derecho de la Propiedad industrial (Porrúa ed., 2011).

79 María Fabiana Jorge, Generación y protección del Conocimiento: propiedad inTELEGTUAL, INNOVACIÓN Y DESARROLLO ECONÓMICO 201-209 (Comisión Económica para América Latina y el Caribe 2008).

80 Agreement on Trade-Related Aspects of Intellectual Property Rights, [TRIPS], April 15, 1994).

81 The Mexican government approved the exception of Article 30 of the Agreement, an action reflected in Article 25 of the Industrial Property Law and addition of Article 47bis to the Regulations of the Industrial Property Law, which is complemented by the Decree 
research to get to know it better (in the case of generic drugs that carry out studies or clinical trials) so that at the end of the exclusive time they can use that knowledge, ${ }^{82}$ and take actions to counteract anti-competitive practices in Articles 8 and 40. Similarly, compulsory licensing consists of authorization given by the government for the manufacturing of a product or the use of a patent process with the permission of the holder of the patent, based on Article 31 of the Agreement in question. The Bolar provision seeks to protect the interests of less developed nations. However, it is the responsibility of each legislator at the national level to contemplate the mechanisms to access these benefits in their intellectual property laws.

It is possible to say that the Agreement decrees the correct application of the elementary principles of the system of commerce and international agreements in the matter of Intellectual property. The basic protection revolves around the following elements: to provide appropriate protection to those of intellectual property rights and the resolution of disputes among the members of the World Trade Organization in a multilateral manner.

On the other hand, it should be stressed that, within the negotiations, the integration of exclusivity periods of test data (or clinical trials) was discussed, to avoid making known the process of elaboration of some invention for a certain time. For example, this modality would help the pharmaceutical industry to retain information to avoid being reproduced by any generic pharmaceutical industry. Another point of controversy was the protection of pipeline patents. ${ }^{83}$ Both of the issues were dismissed. ${ }^{84}$

Within the Doha Declaration, specifically in the sixth paragraph, the TRIPS Council was ordered to find a prompt alternative to the public health problem. As a result, it was agreed to change some provisions of TRIPS to approve the export and import of medicines produced under a compulsory license. However, the compulsory license only applies in case of a national emergency. The country will have to specify what a national emergency is,

published in the Official Gazette of the 2003 Federation, for which Article 167 bis was added to the Health Supplies Regulation. See http://wrwerwipo.int/export/sites/wrwo/scp/en/meetings/session_23/comments_received/mexico.pdf, also http://dof.gob.mx/nota_detalle.php?'codigo $=690516$ Gfecha $=$ 09/19/2003, which is still valid to date, see http://wrwre.ordenjuridico.gob.mx/Documentos/Federal/ pdf/wo88318.pdf.

82 This process can be carried out by the generic drug industries three years before the patent expires with the support of its national legislation, this without the authorization of the patent holder, with the aim to carry out the procedures for the future commercialization of its products, see https://wrere.proceso.com.mx/357431/la-guerra-de-los-medicamentos-2.

83 Also called patent revalidation, which has a relationship with an original patent that expires in the country of origin, that is, if the patent has already expired in the country of origin, it cannot be applied for another 20 years in another PCT member country where the patent had not been requested.

84 In the case of Mexico, the Industrial Property Law did not contemplate the non-revalidation of expired patents in other countries. This was mentioned with post-law reform in transitory number 12 of the Law. 
and only a domestic demand will be met and will have to pay the patent holder. All this has to be clearly specified in National laws, since if it is not; it could enter into some international controversy. This modification entered into force in 2017.85

Finally, it should be noted that the TRIPS Agreement sets the basic provision of the Intellectual Property of international observance. However, in the signing of a Free Trade Agreement, they can be further specified and limited.

\section{Free Trade Agreement}

The TRIPS Agreement is considered the first reference that integrates Intellectual Property with a commercial link. In addition, it is the reference to expand, create or modify national laws that agree with the international common agreements in the matter. Nevertheless, for the practical purposes of defending the interests of the industries that frequently use Intellectual Property (software, audiovisual and pharmaceutical industries), this Agreement is not sufficient, since it is general, flexible and dispute resolution, under multilateral consultations.

Through the Bolar exception in the TRIPS, any interested person can access clinical trials prior to the expiration of the patent. The above is useful mainly for the generic of the pharmaceutical industry since it allows them to enter the market at the end of the validity of a drug patent. The pharmaceutical companies that held the patent considered that this flexibility affected their interests and advocated the extension of protection of this information. ${ }^{86}$ The clinical studies meet the requirements of the country's sanitary regulations and have no direct relationship with the right of ownership of the patent itself, but it is necessary to comply with these standards for the manufacture, sale and distribution of medicines. ${ }^{87}$

Given this scenario, through the United States Office of Commerce, the software, audiovisual and pharmaceutical industries, were one of the main promoters of the establishment of bilateral free trade agreements that specify in greater detail trade, investments, intellectual property, among others, in order to ensure the interests of its representatives, the big industry.

Free trade agreements can define and specify, through articles or clauses, aspects related to commercial transactions, such as tariffs, participating industries, intellectual property, investments, and dispute resolutions. What

85 Ministerial de la Organización Mundial del Comercio [O.M.C.] (DOHA, 2001): Declaración Ministerial WT/MIN (01)/DEC/1, Nov. 20th, 2001, https://wrere.wto.org/spanish/ therwto_s/minist_s/min01_s/mindecl_s.htm.

86 Álvaro Díaz, América latina y El Caribe: la propiedad intelectual después de los TRATAdos de Libre COMERcio 75 (Comisión Económica para América Latina y el Caribe, 2008).

87 Rafael Pérez Miranda, Tratado de derecho de la propiedad industrial (Porrúa ed., 2011). 
makes these agreements a detailed legal tool that can be useful or harmful for the signatories is whether there are equal conditions between the signatory countries, or whether infrastructure, labor, primary resources or broad legal knowledge can have negative consequences such as deepening the technological dependence, which can prevent national industries from developing.

The Free Trade Agreement with North America (NAFTA) links for the first time foreign direct investment to intellectual property. It contains a chapter dealing exclusively with the issue of Intellectual Property, it states that intellectual property is integrated into investments explaining that "investment means: ...(g) real estate or other property, tangible or intangible, acquired or used for the purpose of obtaining an economic benefit or for other business purposes". ${ }^{88}$ In addition, within the Fifth Part called Investment, Service and Related Matters, of Chapter XI, article 1110, it indicates in general terms aspects that contravene the Compulsory License established in the TRIPS Agreement. That is, a contracting State may not use its rules to apply for such a license, nor may it make use of any type of expropriation and/or nationalization of any kind of intangible property by any investor (this includes patents).

The foregoing shows that beyond seeking to encourage the national invention for development through these mechanisms, what is intended is to ensure the investments of companies in intangible assets within the countries with which they establish these treaties, generating disadvantages for countries with low scientific, educational, industrial, commercial development.. In fact, Pérez Miranda mentions that intellectual property rights have evolved from encouraging inventions to be a stimulus for investment. ${ }^{89}$

Finally, it should be noted that another central point of the free trade agreement is the means of resolving disputes or disputes in matters of intellectual property. Given the above scenario, in addition to the hierarchical superiority acquired by these agreements over national laws, it is possible to incur in faults not only in intellectual property but also to attempt an investment, which would lead to two different processes before different authorities. It is worth mentioning that this is the case of several countries in Latin America. ${ }^{90}$

\section{Regional Economic Integration in South America}

The Cartagena Agreement (1969) is a juridical instrument signed by the Andean countries of Bolivia, Colombia, Chile, Ecuador, and Peru; in 1973 Venezuela joined the Agreement while in 1976, Chile retired from it. According to article 1 the agreement aims.

88 North American Free Trade Agreement [NAFTA], Chapter XVII, Chapter XVI, article 1139, as amended, Diario Oficial de la Federación [DOF], Dec. $20^{\text {th, }} 1993$ (Mex.).

89 Rafael Pérez Miranda, Tratado de derecho de la Propiedad industrial (Porrúa ed., 2011).

$90 \quad$ Id. at 68. 
...to promote a balanced and harmonic development of the member countries, through the integration and economic and social cooperation; accelerating its growth and the creation of employment; facilitating its participation in the process of regional integration, to gradually formed a common Latin American market.[It also seeks] to diminish external vulnerability and improve the position of the member countries in the international economic context. ${ }^{91}$

In 1997 this group of nations changed its structure and name to Comunidad Andina de Naciones (CAN) [Andean Community of Nations]. The CAN has a common law on intellectual property rights:

1. Common Regime of Industrial Property is established in the Decisión 486, which norms granting trademarks, designations of origin, invention patents, industrial designs; and also protects industrial secrets, test data, unfair competition linked to industrial property, among others. ${ }^{92}$

2. Common Regime on copyrights and Related Rights embodied in the Decision 351 that recognizes adequate protection for authors and other rights holders over works of inventiveness in the literary, artistic or scientific filed whatever the genre of form of expression and regardless of literary or artistic merit or destination. ${ }^{93}$

3. Common Protection Regime to Rights of Plant Variety Breeders set up in Decisión 345 that protects the new plant varieties obtained by plant breeders. In the Andean sub-region, people who have created or obtained a new plant variety through the application of scientific knowledge enjoy the exclusive right to produce and commercialize said plant for a period of twenty-five years. ${ }^{94}$

4. Common Regime on Access to Genetic Resources embodied in $D e^{-}$ cisión 391 that regulates the obtaining and use of genetic resources for a more fair and equitable participation in its benefits. The community norm expressly recognizes the rights that indigenous, African-American and local communities have over their traditional knowledge, innovations, and practices associated with genetic resources and their derived products. ${ }^{95}$

It is worth to mention that Decisión 486 replaced Decision 344 in the year 2000 and that its amends were oriented to incorporate significant aspects stipulated on the TRIPS, such as national treatment, the most favored na-

91 Acuerdo de Integración Subregional Andino (Acuerdo de Cartagena), May 26, 1969.

92 Decisión 486 Régimen Común sobre Propiedad Industrial, September 6, 2000.

93 Decisión 351 Régimen Común sobre Derecho de Autor y Derechos Conexos, December 17, 1993.

94 Régimen Común de Protección de los Derechos de los Obtentores de Variedades Vegetales, October 21, 1993.

95 Régimen Común sobre Acceso a los Recursos Genéticos, July 2, 1996. 
tion treatment, the scheme of layouts of integrated circuits - referred to the treatment of "microchips" - and the observance of border measures that will result in greater piracy control. It also changed towards a more agile and transparent procedures in registering and granting of trademarks and patents. This common regime is supplementary to current national law in the matter, that is, every country could have a national law on Intellectual Property Rights (IPRs).

Additionally, it is important to highlight that it went beyond the TRIPS, since it incorporated biologic and genetic heritage and the knowledge of indigenous, African American and local communities, as knowledge potentially patentable previous authorization of them using as reference the Biological Diversity Act (2002). ${ }^{96}$ Regarding this last aspect, there are some concerns about patenting traditional knowledge instead of regulating it by customary law, since in these countries there is a customary law at a national level that considers the active participation of indigenous peoples while it cannot be guaranteed at the regional level through the Decision 486. ${ }^{97}$ Also, there are implications of the appropriability of this knowledge once a patent is granted in favor of great corporations and in detriment of the population in general and specifically of these indigenous peoples.

Of these Andean countries, in 2016, Ecuador issued a new law on IPRs, Código Orgánico de la Economía Social de los Conocimientos, Creatividad e Innovación (COES) that, among other things, does not allow to patent traditional knowledge nor genes and genetic material in general. ${ }^{98}$ However, these changes arose some concerns about their negative impact on fostering innovation..$^{99}$

\section{Conclusion}

The evolution of patent legislation formally begins in the fifteenth century with the Venice Statute that arises in the context of commercial economic boom. Among its objectives was commercial independence from other regions in order to strengthen the local economy, integrating and developing skills

96 To Review Changes in Greater Detail, see Falconi Puig \& Abogados Régimen común sobre propiedad industrial. Análisis comparativo entre las decisiones 344 y 486 de la Comunidad Andina de Naciones. IUs Dictio. (vol2, núm. 4, 2000), https://doi.org/10.18272/iu.v2i4.554.

Biological Diversity Act, July 10, 2002.

97 De la Cruz I., Rodrigo Regional Study in the Andean Countries: "Customary Law in the protection of traditional knowledge" (November, 2006) https://wrwerwipo.int/export/sites/weww/tk/en/resources/ pdf/study_cruz.pdf.

98 Código Orgánico de la Economía Social de los Conocimientos, Creatividad e Innovación [Organic Code of Social Economy of Knowledge, Creativity and Innovation], as amended, Registro Oficial Órgano del Gobierno del Ecuador, 9 de diciembre de 2016 (Quito).

99 Sophia Espinosa Colona, Código Ingenios y el sistema de patentes: ¿una propuesta innovadora o la receta hacia un estancamiento tecnológico? IURIS Dictio, Vol. 15, No. 17 (2016), https://doi.org/10.18 272/iu.v15i17.737. 
and knowledge. This ordinance regulated internal inventions and inventions brought from abroad, in addition to locally originated literary works. It is also here that was established the name of patents to the privilege granted, since the so-called privilege was inscribed in the patent letter. It is not until the seventeenth century that the letters patent is granted only to local inventions and those brought from abroad. Furthermore, the inventor is given special recognition as the only one qualified to make the monopoly valid. The United States, having been part of England as a colony, assumes these ideas at the time of independence. Similarly, a few years later France opted for the same alternative.

By the 19th century, commercial conditions, international relations and the insistence of certain nations to expand territorially the validity of patents generated the conditions to establish an Agreement in Paris for the extension of rights to industrial property, as well as penalties for unfair competition. As a consequence, the promotion begins for countries to issue or modify their national patent laws so that they are consistent with the clauses established in the Conventions. Years later they agreed on a single simplified application to apply for a patent in different countries, within the framework of the Patent Cooperation Treaty.

The Second World War changed the economic course of several regions and countries, for example the United States. With the idea of helping lessfavored nations to get rid of the lag, several Trade Agreements of the multilateral type agreed on several countries in the 20th century. An agreement related to Intellectual Property and commercial activities was the TRIPS Agreement, which is the platform for future Trade Agreements. Before the TRIPS, the commercial activity was closed to certain items, after which the pharmaceutical industry was included, and the period of granting patents for product and process inventions was extended, regardless of the place of origin or the technological field, as long as the novelty and industrial application are fulfilled.

This account has always had the monopoly at the center of the discussion: who is considered as inventor; who is the owner; who has the right to monopoly. It also takes into consideration the duration, in what areas, with what requirements, what mechanisms for revocation or prevention of abuse (compulsory license and compulsory work), the publication of the invention for the public domain and the territorial extension of the monopoly.

The international trend is an increase in the degree of legal sophistication in the use and exercise of monopoly; monopoly benefits have been expanded and mechanisms to prevent abuse have been restricted. Intellectual property has even been equated as a form of investment and this implies that monopoly exclusivity mechanisms are extended. The resolution of disputes is favored not only in intellectual property but also in investment matters in favor of particular over social interests. 